\title{
Lessons in Colour-Blind Racism from The Bachelorette
}

\author{
Claudia Franziska Brühwiler
}

\begin{abstract}
The US reality television show The Bachelorette is one of the most successful productions in its genre. It only recently featured its first African American lead, a long-expected departure from the show's dominantly white cast. By analysing how the show discusses race, this article sheds light on how reality television sensationalizes racism. Racism in reality television is not, as the production wants to make viewers believe, the result of individual cases of prejudice, but a problem of those responsible in the control room and, arguably, of those tuning in.
\end{abstract}

Keywords: The Bachelorette, colour-blind racism, Eduardo Bonilla-Silva, popular culture, race talk, racism, reality television

Résumé : L'émission de télé-réalité américaine The Bachelorette est l'une des productions dans le genre ayant eu le plus de succès. Ce n'est que récemment qu'elle a mis en vedette sa première célibataire afro-américaine, un virage longtemps attendu de la part d'une émission dont les personnages sont surtout blancs. En analysant comment l'émission discute de race, cet article met la lumière sur la manière dont la télé-réalité dramatise le racisme. Contrairement à ce que la production veut faire croire aux téléspectateurs, le racisme en télé-réalité n'est pas le résultat de préjugés individuels, mais bien un problème lié à ceux responsables de la salle de régie et, sans doute, de ceux qui regardent l'émission.

Mots clés : The Bachelorette, racisme indifférent à la couleur, Eduardo Bonilla-Silva, culture populaire, race, racisme, télé-réalité

\section{Introduction: Post-Racial/Post-Racist Fantasies}

In 1903, W.E.B. Du Bois claimed that the "problem of the twentieth century is the problem of the colour line,- the relation of the darker to the lighter races of men in Asia and Africa, in America and the islands of the sea" (17). More than one hundred years later, 
Patricia Hill Collins could see the problem persisting, albeit in different ways: "The problem of the twenty-first century seems to be the seeming absence of a colour line. Formal legal discrimination has been outlawed, yet contemporary social practices produce virtually identical racial hierarchies as those observed by Du Bois" (32; original emphasis). Rather than appearing in blackface and segregation laws, today's Jim Crow has taken on the shape of the so-called new racism or colour-blind racism, which drowns out any accounts of inequality or downplays their importance. The language of colour-blind racism is codified, and its reasoning follows a variety of frames that are confirmed by the media, not least in popular television programs.

Television has emerged as a major source of discourse on public thought over the past few decades, and one type of program that has gained particular scholarly attention is reality television. As a professor of political science observed, "Regardless of how many academic books and journal articles are assigned in an undergraduate class in a given semester, some students will likely spend more time watching reality television than reading" (Dreyer 409). Undergraduates are far from alone in their predilection for such formats, which, as with the media in general, influence viewers' perceptions of reality. In the case of reality television, this impact is particularly troubling because of the way these shows blur the boundaries between fiction and reality. As will be discussed, reality television also maintains the illusion of an America where the colour line has disappeared and no longer matters.

The Bachelor and The Bachelorette are among the most popular reality television shows, making them-as the title of Amy Kaufman's recently published book indicates-America's Favorite Guilty Pleasure. The shows blend 1950s' primness with the multi-optional dating world of today. The franchise has its viewers experience Cinderellalike fairy tales of formal courtship where sex is never mentioned but always implied. Happiness without a marriage licence does not exist-confirming a conservative dream with the necessary naughty touch of sexual innuendo and a harem of eligible partners. Fittingly, the show tries to ignore the multicultural reality of America. In the 1950s, America largely disapproved of inter-racial marriages, whereas today, they are on the rise. The Bachelor franchise, however, has long remained, to quote Rachel E. Dubrofsky, a world "in which only white people find romance, while [men and] 
women of colour work to facilitate the coupling of white people" (39). Since its first episode seventeen years ago, The Bachelor has never featured a black lead; and until early 2017, all twelve "Bachelorettes" were white. This is reflected in the show's viewership, as its audience tends to be 80 per cent white (Arthur). But finally, things changed with lucky number thirteen: meet Rachel Lindsay, a (then) thirty-two-year-old attorney from Dallas, Texas, who had the pleasure of meeting thirty-one men and handing out roses to those in whom she was interested.

Producers of the show and the $\mathrm{ABC}$ network promised viewers a season that would take the format in a new direction, contributing to the nation's conversation on race. They finally wanted to fulfil the promise that love does not see colour; produced love, however, does, as I will show. More specifically, I will argue that Season Thirteen of The Bachelorette is an exemplary case of "colour-blind racism." Not only does the show perpetuate the language of colour-blind racism, but it also demonstrates the impossibility of engaging viewers in a meaningful conversation on race as long as a predominantly white production team is steering the dialogue with a white audience in mind. In other words, while reality television programs in the tradition of The Bachelor try to convince viewers that racism is, if not a thing of the past, just an individual sin, The Bachelorette undoubtedly demonstrates that racism is an issue at both the individual and production level-that is, at the collective level.

\section{From Jim Crow to "Colour-Blind Racism"}

Living in a truly post-racial society would mean that race, "once a significant and substantial predictor of various behavioural patterns and life outcomes" (Hero, Levy, and Radcliff 41), no longer determines an individual's future, be it in the form of educational or economic opportunities, the likelihood of being arrested or incarcerated, or the chance of becoming a victim of police brutality. Unfortunately, we all know that this is not the case. Although Jim Crow's blackface make-up has been removed and the struggles of the civil rights movement have, to some extent, paid off, ironically, the very achievements of the 1960s have made it hard for Americans to admit that they are still far from a post-racial and post-racist reality.

Overt racism persists, as recent events have shown, but racism is even more common in its less blatant form, shrouded by a colour-blind 
curtain. As sociologists like Patricia Hill Collins and Eduardo BonillaSilva have pointed out, "new racism" or "colour-blind racism" is equally successful in maintaining a society based on white privilege. Colour-blind racism is based on the shared belief that "[s]ocial changes that took effect during the civil rights movement benefited African Americans and that, consequently, America has lived up to its promise of equality" (Littlefield 676). In other words, most white Americans believe the civil rights movement to have been successful in effectively ending racial inequality. If the latter still exists, goes their reasoning, it is the fault of those who have not adapted to the new circumstances and "failed to take advantage of opportunities created by the civil rights revolution" (Brown et al. 1). Accordingly, whites are increasingly hesitant to endorse affirmative action or similar measures: if this is a colour-blind society, why then "privilege" minorities? Some go even further, claiming that, in fact, whites are far from privileged in the current situation, but are rather put at a disadvantage and may even experience so-called reverse racism. In reply to such assertions, researchers have remarked acerbically that "[ $\mathrm{t}]$ he last thing a fish notices is the water" (Brown et al. 34).

Specifically, white Americans frame racial inequality in different ways to justify it. According to Bonilla-Silva, these frames include abstract liberalism, naturalization, cultural racism, and minimization of racism (Bonilla-Silva; Bonilla-Silva and Dietrich). By "abstract liberalism," he refers to those opposing affirmative action as breaching liberal tenets, namely, the ideals of equal opportunity and meritocracy. People resorting to abstract liberalism claim that affirmative action is merely an exercise in legislating moralitywhich, in the end, is not the responsibility of a liberal democracy. "Naturalization" is, per Bonilla-Silva, the least-used frame to explain persistent racism: it normalizes racial inequality by claiming that it is inherent because of innate racial differences. By contrast, "cultural racism" is more frequent: while cultural racists do not consider minorities as "inferior biological beings," they biologize "their presumed cultural practices" (Bonilla-Silva and Dietrich 193) and blame the victims of racial inequality for lacking effort, having inappropriate values, and so on. Finally, another oft-heard set of claims is encapsulated by the frame referred to as "minimization of racism." This refers to the common belief that discrimination is a sin of the past and that those who claim to have been subject to discrimination are merely looking for an excuse for their personal failings, effectively playing the infamous "race card." 
These frames come to the forefront in what has been termed "race talk" - conversations on race, race relations, and the problem of discrimination. According to one commentator, "Race talk is not only a clash of racial realities, but re-enacts the differential power relationship between a dominant group master narrative and the less powerful, socially devalued group counter-narrative" (Sue 24). As a consequence, whites tend to avoid race talk altogether, as psychologist Derald Wing Sue observes, typically by invoking different protocols that call for silence: the politeness protocol, the academic protocol, or the colour-blind protocol (24-5). The politeness protocol precludes race talk, as whites fear to be seen either as racists or as "bleeding heart liberals," while members of a minority do not want to be accused of playing the so-called race card. Both sides try to avoid situations that put one or the other into a defensive mode and may cause rifts. According to Sue, this happens frequently in academia, where racism may be addressed theoretically but not as an institutional problem in higher education. Finally, under the colour-blind protocol, whites refuse to see or acknowledge the existence of race, again for fear of being considered racist and prejudiced (26).

\section{Race, Reality Television, and The Bachelorette}

Neither a post-race nor a post-racist society has become reality for Americans (or for other nations, for that matter), yet such escapist fantasies become more attainable to them once they switch on their TV sets. As media scholar L.S. Kim observed, "Americans take comfort knowing (and seeing) that in Reality TVland, if not in real life, race is of no consequence." Reality television, once a fringe phenomenon on the small screen, blurs the boundaries between fiction and documentary so successfully that it has become a constant fixture in modern television programming. As a consequence, the way reality television programs discuss race has become relevant to researchers of different disciplines. In other words, reality television's claim that race does not matter does matter: as Amy Hasinoff explains, the media in general influences how viewers understand race, and reality television is particularly apt to do so, as it plays with the illusion of featuring "real" people in "actual" situations. Consequently, reality television's representation of race relations is particularly problematic, as it can perpetuate stereotypes and assume the logics of colour-blind racism without being challenged.

Although reality television conveys the illusion that viewers witness what has "actually" happened on the show's set, it still depends 
on traditional narrative patterns, using an exposition followed by rising action and conflict, serving up both villains and heroes. The viewer tends to forget, though, that played time and playing time often diverge, and alleged villains may be edited into life to fulfil a role. Stereotypes deliver the necessary narrative shortcuts (see Pardo; Tyree). The stereotyping of African Americans in the world of film and television is a much-debated issue, as it has been present practically as long as the medium itself. In 1917, The Birth of a Nation not only fed its audience images of African Americans as persons of "servitude, crime, savagery, inferiority, and animalism" (Littlefield 679), but also proved the power of film by inspiring the renaissance of the Ku Klux Klan. Generations of moviegoers and TV viewers have been exposed to stereotypical representations of African Americans, from angry Sapphire in the comedy show Amos ' $n$ ' Andy (1951-3) and her modern incarnations to the many embodiments of Jezebel, the eternal temptress, as well as their male counterparts, ranging from the not-so-bright Sambo to the modern-day pimp (see Boylorn; Tyree). As communications scholar Tia Tyree has shown, these stereotypes likewise populate current reality TV shows.

Moreover, reality TV is just as much engaged in colour-blind racism as other types of programming (see Drew; Hasinoff; Kraszewski; Shugart). Overt racism is avoided and race relations never discussed; diversions from the colour-blind ideal are represented as exceptional and mere examples of individual prejudice (Hasinoff 328). Colour presumably does not matter, but whiteness remains the norm and the context, with coloured characters often being of minor importance. Just as many a prime-time television show has its "token minorities" assume minor roles, reality TV displays similar tendencies (Chidester). It has been demonstrated that the appearance of two coloured contestants or characters usually leads to their being characterized as opposites, with the one who comes across as more adapted to the white context being represented as morally "better" (Drew 331; Pardo 71). One show serves as a particularly good example of the "presence of absence" (Chidester 157) of minorities in the genre and how whiteness is usually taken for granted by both participants and viewers: Survivor regularly places a group of strangers in an isolated location to undergo a Robinson Crusoe-like experience. In its thirteenth season, its contestants were divided into four tribes-according to their race. Interestingly, the members of minority groups noticed right away that they must have been brought together by their shared roots and appearance, 
while the white contestants only noticed this once they were confronted by the other tribes.

The Bachelor and The Bachelorette fit neatly into the universe of predominantly white reality television shows that have an awkward relationship with diversity. The dating reality show franchise features a single man or woman seeking a future spouse among a group of twenty or more eligible contestants. After a series of group dates, two-on-one dates, and one-on-one dates, frequently in exotic locations, the lead hands out roses to those contestants he or she wishes to stay on the show until, finally, it is time for a proposal. The pool of eligible contestants is dominated by a mix of white men or women every year, and the lead has, with two exceptions, always been white. This lack of diversity has been observed not only by critical viewers, including critics and bloggers, but also by other television producers. Consequently, $\mathrm{VH} 1$ advertised its own dating reality format, Flavor of Love, starring the rapper Flavor Flav, as "the Black-chelor" (Dubrofsky and Hardy 376). Indeed, since its first season in 2002, The Bachelor has never featured a non-white man as its lead, with the Latino exception of the American-born Venezuelan Juan Pablo Galavis in Season Eighteen. Similarly, it took twelve seasons of The Bachelorette for Rachel Lindsay to become the first black lead across the entire franchise. Naturally, the cast of the show is never entirely white, but, as is the case with many television programs, men and women of colour appear only briefly, and their story-lines remain undeveloped, providing mere "B-Plots" (Showler, ch. "Not Going to Say Words: Race"). As a result, viewers tend to perceive them as a mere back-drop and frequently fail to remember them at all. In her assessment of the show, gender studies scholar Rachel E. Dubrofsky concluded that the program is clearly raced: "The series is a context in which only white people find romantic partners, while women of colour work to facilitate the coupling of white people" (39). She compares the setting of the show to Western fantasies of the oriental harem, allowing white men to transgress the monogamous norm to which they eventually return. Non-white women become desirable objects, to be discarded once the choice of a white long-term partner is made:

The very form of The Bachelor naturalizes the desire of white men for women of color as a means of preparing for union with their ultimate partners, white women. In The Bachelor, whiteness is an implicit prerequisite for finding a mate. While many of the white women do not find 
love with the bachelor, they may be the center of the storyline for one or more episodes. In fact, the more spectacularly the white women fail to become the bachelor's partner, the more screen time they get. This is not the case for women of color, who work only to frame the narrative about white people forming a romantic union. (Dubrofsky 40)

Dubrofsky's analysis coincided with the season featuring Travis Lane Stork as the lead-then completing his emergency medicine residency at Vanderbilt University, he would move on to host a medical talk show. Writing at that time, Dubrofsky naturally could not foresee that, nine years later, a woman of colour would become the star of the series. Prior to this breakthrough, other small steps were made: a woman with Filipino roots would be the last woman standing and get an engagement ring from Bachelor number seventeen, two years after a Latino contestant got down on one knee for Bachelorette Ali Fedotowsky. As I show in the following, however, an African American lead hardly means a breakthrough in terms of diversifying one of the most successful reality TV shows to date.

\section{The Making of the First Black Bachelorette}

"You're not even in the running for love unless you fit a very narrow ideal of Ken and Barbie doll physical beauty . . . If you're black on The Bachelor or The Bachelorette, you're usually kept around as a courtesy for a few weeks before being ejected," observed legendary former NBA player and now cultural critic Kareem Abdul-Jabbar. Only a few months later, he would appear as a guest on the show, watching the male contestants vie for the attention of the thirteenth Bachelorette from the sidelines of a basketball court. Why the sudden change of heart?

A show that was once sued by two men for racial discrimination (Deggans; Lawson) finally chose a black lead: Rachel Lindsay, a then thirty-two-year-old attorney from Dallas, Texas, would be the one to hand out roses to the more promising contestants. Previously, she had caught viewers' attention in the twenty-first season of The Bachelor, in which she became one of the last three women hoping to get a proposal from Nick Viall, a former software salesman and seasoned Bachelorette contestant. Picking Lindsay as the lead clearly meant a change for the show's producers, as they signalled by communicating their decision earlier than usual. While fans are normally kept guessing as to who would next keep them 
entertained until the show's finale, Lindsay was announced as the new Bachelorette before the conclusion of the Bachelor season on which she appeared-even while episodes were still airing that featured her as one of the women declaring their feelings for Viall, in fact. This kept loyal followers speculating whether producers simply wanted viewers to get used to the idea of a black lead or whether they wanted to encourage more black men to apply as prospective contestants. Moreover, the first four men competing for her hand in marriage had already been introduced to her before the filming of her season officially started. To emphasize that things should work differently with an African American lead, two of those four men were black. One of the white contestants, though, already showed the level of awkward race talk that would be a red thread throughout the season. Upon meeting her, a suitor said, "I am ready to go black and never go back" ("After the Final Rose").

These beginnings inspired the comedians of Saturday Night Live to spoof the show, joking that its producers were working on their "most progressive season yet," which would be "breaking down barriers." In tune with the first encounter between Lindsay and four of the contestants, SNL accurately predicted that race talk would be a recurring theme during the whole season, but it had its fictional contestants be considerably more direct about their qualms than the actual ones would be: "Can you cut me before we do the meet-theparents thing?" ("Cut for Time").

Lesson 1: Even if the show's production team avoids the typical black stereotypes, old habits die hard. Unless viewers and contestants alike are made aware of their unconscious thought patterns, they are unlikely to abandon them.

Stereotyping of black participants in reality television shows is a common ailment. Thankfully, the thirteenth season of The Bachelorette tried to bring together a more diverse cast of contestants than it usually would, with close to half of the thirty-one men identifying as non-white or half-white. The set of black men was particularly remarkable, as they were more accomplished than the average participant in a reality television show, without any of the usual social media influencers, bloggers, or personal trainers among them. In fact, several had finished graduate school, as a quick look at their profiles shows: they included a recruiting consultant with an undergraduate degree from the Fashion Institute of Design and 
Merchandising, a motivational speaker and coach with an undergraduate degree, a childhood acquaintance of the lead who had a master of fine arts degree and a master's degree in business, a sales manager with a college degree in politics, a personal injury lawyer, a professional wrestler, a senior inventory analyst with a graduate degree, and, finally, a former recipient of a Fulbright Scholarship who is fluent in five languages (Carbone, "Rachel's Guys"). They were thus the type of contestants who could not be easily presented as embodiments of typical black stereotypes. Instead, they themselves played with stereotypes, by adopting certain mannerisms, for example, and they would make, as one contestant recounted in an interview, "racial jokes" (Carbone, "Podcast \#41"). The quips were, however, never aired, probably because production struggled with the way it could and should address the diversity of its cast.

While production tried to avoid overt stereotyping, it still managed to sometimes serve typical images of blackness. For instance, it chose to advertise the new Bachelorette as the "baddest girl," highlighting the reference to the world of rap and hip-hop with a song by the R\&B group Fifth Harmony. Fittingly, one of the group dates had contestants come up with their own rap lyrics, with one of the top two white contestants rhyming that Lindsay was "a girl from the hood." A commentator for Essence magazine reacted in disbelief: "Whet [sic]? Rachel grew up with two church-going parents who are still together in suburban Dallas, where she spent her summers at swimming camps and ran track" (Jackson). Such incidents are, however, more telling of the persistence of stereotypes and thus the kind of colour-blind racism displayed by many contestants rather than of stereotyping strategies of the production. Instead, producers were regularly trying too hard, as a New York Times critic observed, to show "kumbaya images of postracial harmony" (Caramanica and Hess) —only to then contrast these images with the opposite, as Lessons 2 and 3 will show. At the same time, the team made a casting decision that would make the problem of race relations a central issue, as will be discussed below.

Lesson 2: Black contestants are familiar with the language of colour-blind racism, whereas whites consider it taboo to even mention the problem by its name. While the show brings this to viewers' attention, it fails to provide an escape from this impasse. 
Derald Wing Sue has observed how stilted race talk tends to be in colour-blind America, pointing out how both whites and blacks have developed avoidance strategies or how they resort to codified language. Season Thirteen of The Bachelorette is exemplary of the difficulty many have in addressing racial issues directly, employing many of the colour-blind frames white people tend to use to justify or discuss certain societal issues. During past seasons of the show, these phenomena have been addressed sporadically. For instance, in Season Twenty of The Bachelor, a black Haitian-born veteran named Jubilee Sharpe remained among the circle of eligible women for several episodes. Her prospects seemed good, and her story received more airtime than had previously been the case for any black contestant. However, as the season progressed, her fellow contestants started voicing their concerns and overtly doubted that she would make a suitable match for the lead, an observant Christian from the Midwest. One blonde co-contestant felt that Sharpe would not fit in "with all the other soccer moms" (Rankaduwa). ${ }^{1}$ What, upon first hearing, sounds innocuous in fact echoes the typical codes used by white reality television contestants when they criticize black contestants as not fitting in, lacking team skills, or making others uncomfortable, as observed by Elizabeth Drew in her study.

During Lindsay's season as the Bachelorette, many contestants tiptoed around the question of race and inter-racial relationships, assuaging the lead's concerns that families and friends might not be accepting of her. While Lindsay herself repeatedly brought up the question of acceptance, she never spelled out why she had these concerns in the first place. Fittingly, during her Bachelorette season, it was only during a "hometown date," a visit with the families of each of the final four men in the running, that the matter was named. At the home of the only remaining black contestant, Eric Bigger, an aunt cheekily commented: "Let's bring up the R-A-C-E word, 'race.' Everyone's like, 'first black Bachelorette!'-how are you dealing with that?" ("Week 7"). Viewers intrigued by the charismatic aunt would later learn that it was no coincidence that she would turn out to be the only one to address the proverbial elephant in the room. Bigger's aunt, Vernā Myers, is a graduate of Harvard Law School who has written about racial relations and shared her thoughts in a TED Talk (Myers and Fawal). Myers's playful spelling of the word that others dared not mention confirmed what Sue, Bonilla-Silva, and others had observed about today's America and its inability to 
address racial issues in an upfront manner. Beyond this, however, the show would further highlight how white Americans also shy away from identifying the more insidious colour-blind racism.

The problem of colour-blind racism manifested itself in one contestant in particular: a bartender from Nashville and graduate of Florida State University, Lee Garrett. ${ }^{2}$ A GQ critic described Garrett as "a vaguely elfin aspiring country singer who looks and talks like a man who's definitely worn a bright red baseball hat with white block lettering on the front before" (Willis). While on the show, Garrett never made any overtly racist comments, but early on, he conveyed a certain mastery of codified language, suggesting that he had internalized the core assumptions of colour-blind racism. In this vein, he described himself as "the only country boy in the house," who would therefore have "problems with some of the guys here." To make sure that viewers would understand the subtext, production then cut to two black contestants who would, during the first five episodes, be antagonized by Garrett. He openly admitted that provoking other candidates amused him, and he kept his word by, first, mentioning that one of the black contestants, Bigger, was not on the show for "the right reasons" - a cliché phrase used in many seasons. Bigger was visibly and audibly upset; Garrett reacted in mock disbelief, underlining that he wanted to be kind to his fellow contestants and repeatedly stressing his "love" for the others. At the same time, he started to characterize the behaviour of black fellow contestants as "aggressive," thus helping himself to one of the oldest stereotypes circulating about black men ("Week 2").

In particular, he targeted fellow contestant Kenny King, fittingly a professional wrestler, whose wrestling persona, "The Pretty Boy Pitbull" (Carbone, "Rachel's Guys"), plays with different stereotypes. Garrett claimed that King had pulled him out of a van while en route to a location, and later suggested to Lindsay that King had "a dark side," particularly under the influence of alcohol. The latter disputed the accuracy of the account and was irritated by the constant allegations of being "aggressive." When Garrett expressed confusion as to why King would take issue with his choice of word, fellow black contestants tried to educate him. One of them, Will Gaskins, took him aside, explaining that " $[\mathrm{w}]$ hen you call him aggressive, there is a long-standing history in this country of regarding black men in America as 'aggressive' to justify a lot of other things." Garrett became defensive and showed frustration that King had "played 
the race card" ("Week 5: Part 1"). By mentioning the infamous race card, Garrett applied one of the frames suggested by Bonilla-Silva, minimization of racism, to which he would frequently resort: he claimed ignorance of the potentially raced nature of his words, repeatedly couched problematic statements in declarations of affection and respect for his fellow contestants, and portrayed himself as a victim of calculated misunderstandings and aggressions.

Not only were his black fellow contestants aware of this, with King notably calling Garret an "alternative facts piece of garbage" in episode four ("Week 4"); the white contestants also expressed their discomfort. However, the way they talked about the perceived tensions suggested an inability or a lack of vocabulary to engage in race talk and effectively address colour-blind racism. They clearly shied away from calling the problem by its uglier name. In an exemplary fashion, contestant Dean Unglert explained to a producer during a so-called in the moment shot that "[t]he only people I have seen Lee pick fights with are people he is not used to seeing on a daily basis from a cultural perspective." When, off-camera, a producer tried to prompt Unglert to say explicitly what he meant, the latter replied, "You know exactly what I mean."

In other words, white contestants show an awareness of racial tensions but try to keep to the colour-blind fiction of reality television by steering clear of the issue. As Showler demonstrates, their refusal to address racism directly places the burden on the black contestants to edify a contestant like Garrett who is piercing the post-racial fantasy bubble. By denying themselves the right-or duty-to intervene and speak up, they are forcing their black counterparts into repeatedly addressing the issue themselves and thus emphasizing their "otherness," an aspect that few of them want in the first place. Yet equality in the world of produced love remains utopian.

Lesson 3: Racism in reality TV is not, as production wants to make us believe, an individual case of prejudice, but a problem of those behind the camera, those responsible in the control room, and, arguably, those tuning in.

The suspicions viewers and contestants alike had about Garrett were confirmed once media outlets started to circulate tweets he made in 2015 and 2016. These proved not only that Garrett was fluent in the frames of colour-blind racism but also that he did not 
shy away from overt racism. Adopting the frame of abstract liberalism, he once tweeted that "[if] you put the colour of a person's skin above the quality of work of any other, you are a racist," denouncing "minority privilege" as "racism at its finest," and suggesting that the Irish were America's "forgotten white slaves" (Gray and Fallon, "ABC Cast"). Thus, Garrett questioned the need for affirmative action in post-civil rights movement America, reframing it as a case of reverse racism. He went even further with an openly racist comment likening the National Association for the Advancement of Colored People (NAACP) to the Ku Klux Klan.

Bachelorette Rachel Lindsay learned of Garrett's unsavoury Twitter history at the same time as the rest of the tabloid-reading publicduring the airing of her season-and thus could not confront him about his statements during the show's regular episodes. The penultimate episode, however, is dedicated to a "Men Tell All" format that reunites the cast and gives the host an opportunity to bring up controversial issues-including Garrett's performance and statements. He partly seized the opportunity to denounce his past statements as overtly racist but failed to acknowledge many of his perceived shortcomings during the season. Instead, the episode showed, again, how black contestants were naturally more aware of colour-blind racism, but also how they possessed the vocabulary to explain it, while production itself struggled with the whole issue. In this vein, one of the contestants explained to Garret that he should acknowledge "the kind of invisible racism in your mind... the racism [that] is ingrained in your behaviour" and "implicitly embedded in your mentality" ("Men Tell All"). After the show, two black contestants, among them King, shared this assessment, expressing a belief that Garrett's behaviour and mindset were more a result of his background and circumstances than a sign of being an incorrigible racist. One speculated that Garrett had probably not interacted with many black men prior to filming and thus did not understand them; as a consequence, the latter tried to explain to Garrett the aims and nature of the Black Lives Matter movement (Carbone, "Podcast \#41"). King himself thought that Garrett was not a "real racist," as he "could not smell the Confederate flag on him" (Carbone, "Podcast \#44"), but rather saw in him a person trying to reconcile contrasting views held in himself.

In "Reality TVland" (Kim), racism tends to be presented as a personal shortcoming, a problem of individual contestants/characters 
but not of society as a whole-nor of the production companies steering the narratives unfolding on-screen. In this manner, Garret was portrayed as an anomaly, an aberration from the post-racist, post-racial norm. The problem is, as we know, more deep-seated. In the case of The Bachelorette, any attempt at creating a truly breakthrough season in terms of diversity had to fail due to production's own take on race relations. Analysing the season of Survivor featuring raced tribes, Elizabeth Drew spoke of a "spectacularization of race" (65)—and so, Season Thirteen of The Bachelorette too amounted to a spectacularization of racism.

As a critic with $G Q$ observed, every season of the show features its so-called villains, "but the villainy is supposed to come from dumb, petty feuds that erupt after two people passionately argue about which one of them is more in love with a woman with whom they've spent a combined total of, like, an hour" (Willis). Villainy usually concerns the question of whether a contestant is on the show for "the right reasons" and whether he or she is ready for marriage or is "wife or husband material." ${ }^{3}$ With the casting of Garrett, production deliberately redefined "villainy." Although the show's host denied on Twitter any prior knowledge of the issues that would emerge, a blogger rightly pointed out that they should have known, given the extensive background tests run on each contestant (Carbone, "Bachelorette Rachel"). ${ }^{4}$ Moreover, Garrett was contacted through Facebook - that is, he was scouted by production based on his presence on social media and did not apply to be on the show on his own-making it highly unlikely that his Twitter feed had not been examined. One is thus forced to conclude that production consciously created a "powder keg of uncomfortable racial dynamics" (Coscarelli and Ganz ) to make sure that race talk would ensue in one form or another. Instead of trusting their lead to provide a narrative of her own, production seems to have instigated racial drama. At the very least, editors decided to make racial tensions one of the major story-lines of the season.

Filming a two-hour episode of The Bachelorette takes several days, usually a week, such that told time and telling time diverge. It is thus at the director's and production's discretion which story-lines to feature and develop for the viewers. In episode three ("Week 3"), the focus started to shift toward Garrett; it would remain on the fights he picked with black contestants until his departure in episode six ("Week 5: Part 2"). Even if these racial tensions had been 
the major event of the episodes without narrative emphasis, their framing clearly testified to production's intention: in the trailer for episode six, the two-on-one date featuring Lindsay, King, and Garrett is stylized as "an Epic Battle between Good and Lee-vil," with soundbites by King describing his counterpart as a "Southern piece of garbage" and a "snake," Lindsay repeating allegations of violence, and Garrett mentioning again "the race card." In an earlier promotion, the trailer even combined images of a verbal altercation between Garrett and King with footage from a later episode in which the latter had a small laceration on his forehead. Thus, the show insinuated that the conflict might turn physically violent, believing its viewers to be drawn to such displays of inter-racial violence. Apparently, production did not consider such images to be triggering, only taking into consideration the standpoint of white viewers who could please themselves in their outrage at the racism shown, re-affirming their view that such behaviour is not the norm, that America generally does not see race. However, making racism a point of entertainment and a source for self-righteous affirmation is racist in itself.

Lesson 4: In colour-blind reality $\mathrm{TV}$, inter-racial relationships are desirable-if they include a white person, and specifically a white man.

While the media caught on quickly to the racial tensions in Lindsay's season, few addressed one of the central concerns the lead herself voiced at several points. She explained how much pressure she felt as the first black Bachelorette, not only in terms of being a role model and a representative of "the black community" but also in the choice of contestants she would keep in the running. Specifically, she hinted at the backlash she might experience for sending black contestants home, all the while harbouring concerns over whether prospective white in-laws would be accepting of her. In other words, Lindsay was pointing to the problem of inter-racial relationships and the prejudices against them.

In the US context, these concerns are still common, particularly among black women. The intermarriage rate of black women lies at 12 per cent, and with black men at 24 per cent. Until the Supreme Court's 1967 ruling in Loving v. Virginia, all Southern states enforced anti-miscegenation laws (Pascoe 48-9), echoing the segregation maps pre-Brown v. Board of Education. But even in the rest 
of the country, inter-racial couples were anything but the norm, as reflected in popular culture. While the audience of Birth of a Nation had already been exposed to black men as rapists of white women, it was only after Loving that a romantic inter-racial relationship would be shown on the big screen: Guess Who's Coming to Dinner (1967) has a young white woman introduce her black fiancé to her professedly liberal parents who, though in favour of racial equality, cannot hide their reservations (Butter 179-81). On television, the first inter-racial kiss happened a year later on a science fiction show, Star Trek, in which Captain Kirk would embrace Lieutenant Uhura-albeit as a result of torture and against their will (183-5).

Fifty years after Loving, the Bachelor franchise finally summoned the "courage" to have a black lead come to the final four contestants' hometown dinner. Why did it choose the more junior show, The Bachelorette, for this step, and not the more highly rated Bachelor? An easy answer would be that none of the black contestants had been among the final four in any of the Bachelorette seasons, while Lindsay had. This argument is, however, invalid, as the show had recruited other contestants as leads before. And as faithful viewers and critics of the show have pointed out, there had, every now and then, been an interesting black contestant who could have carried the show as a lead. The answer instead seems to be rooted in the greater reservations in American society against black men dating white women-which might be even worse if the black man in question gets to date an entire harem.

In his seminal treatise on Sex and Racism in America (1965), sociologist and writer Calvin C. Hernton relates a story from his student days when he came across an intriguing book at his college library: What the Negro Wants-which was sex with white women, he would learn (66). As a survey by Gunnar Myrdal in the 1940s had shown, this was a widely held belief in the Jim Crow-era South, as Myrdal's white interviewees felt that black people desired "intermarriage and sexual intercourse with whites" the most, whereas his African American interlocutors expressed economic opportunities as their primary concern (Hernton 3). In fact, the concern about black men lusting for white women strongly informed the early antimiscegenation or anti-amalgamation laws in the United States, which initially did not encompass intercourse between white men and black women. bell hooks argues that this preoccupation is still prevalent in US society: "That story, invented by white men, is 
about the overwhelming desperate longing black men have to sexually violate the bodies of white women ... It is a story of revenge, rape as the weapon by which black men, the dominated, reverse their circumstance, regain power over white men" (58). It is thus fair to argue that production recoiled from casting a black Bachelor to avoid triggering such associations.

This suspicion is corroborated by the events surrounding the filming of the summer spin-off of the Bachelor franchise, Bachelor in Paradise $(B I P)$. For BIP, cast-off contestants of former seasons of the two other shows are brought together to a beach resort in Mexico to date each other. Filmed right after The Bachelorette, the 2017 cast included DeMario Jackson, who had been dismissed during Lindsay's season for having had a girlfriend back home, as well as Corinne Olympios, a blonde model and influencer from Florida who had been considered a villain during Season Twenty-One of The Bachelor. Filming of the show stopped after one day due to allegations of sexual misconduct-allegations against Jackson, a six-foot-four black man. The accusations were placed by two female producers who had not witnessed, but rather heard of, a sexual encounter between Jackson and an intoxicated Olympios-rumours that soon circulated as scandalous accounts over online media. In the end, investigations exonerated Jackson, not finding any proof of misconduct on his part. In dubio pro reo is, however, not a principle that online communities live by, and thus Jackson's social media profiles were targeted with racial slurs. Encounters like his and Olympios's have been rather common in the course of the show, but, as another black contestant from Lindsay's season observed, "It wasn't until the black man [Jackson] got into the mix that this was deemed as no longer acceptable" (Madison). The stereotype of the "black brute" (Butter 175) apparently resurfaced, making it easy for observers to believe spurious allegations. A black Bachelorette was consequently a lesser risk for production than her male counterpart would be.

Throughout her season, Lindsay repeatedly expressed concern at the prospect of meeting potential in-laws who might be critical of interracial relationships. At the same time, she stressed that she was looking for a man who was ready for marriage and who would not shy away from such a commitment. Still, viewers were upset that she broke up with finalist Peter Kraus, a personal trainer from Wisconsin who did not feel ready to get engaged, and instead said yes to a proposal by Bryan Abasolo, a chiropractor from Miami with Colombian roots. 
Interestingly, critics refrained from commenting on the inter-racial as well as intercultural aspect of their relationship, rather focusing on Lindsay's rejection of the Midwestern all-American man, Kraus.

The presentation of Abasolo's TV persona was, from the beginning, raced. He frequently played with the fact that he was bilingual, he introduced himself in Spanish, and he used his hometown date to visit Calle Ocho, the heart of Cuban Miami, where the two would play dominos with elderly Latino men, thereby celebrating many a cliché. Throughout the season, he was reduced to an all too charming, all too smoothly talking poster boy of Latino charisma, with the audience conveniently ignoring that, among Lindsay's finalists, he was the only one who could match her educational background and who mirrored many of the values she stood for. In addition, Abasolo's mother was portrayed as the stereotypical overprotective Latina who cannot let go of her children and would murder for them. (Naturally, Abasolo's last relationship had fallen apart due to a conflict between the girlfriend and his family.) For the (white) viewer, it seems, choosing a Latino over a white man from the Midwest did not constitute Lindsay's envisioned happy end. If the show had to end in an inter-racial engagement, it had to be in black and white, not Latino and white.

\section{Conclusion: Missed Opportunities}

Reality television is, in conclusion, probably an unlikely setting for a post-racial revolution to take place. It would require a black bachelor dating a diverse cast of women without anyone tweeting about it being controversial, problematic, or revolutionary. For the time being, neither the executives of mainstream television channels nor the American audience seem to be ready for this kind of outcome. On the upside, however, Season Thirteen of The Bachelorette succeeded in inspiring the kind of conversation on race that America should be having continuously, and not only in the wake of hate crimes and racist tweets from another former reality TV star.

\section{Acknowledgements}

This article is based on my Habilitationsvortrag held on 13 November 2017 in St. Gallen, Switzerland. I thank the faculty members of St. Gallen's School of Humanities and Social Sciences and other audience members for the constructive debate. I am also indebted to Professor Christoph Frei and Professor Yvette Sánchez for their comments. Moreover, I am grateful to the 
anonymous reviewer for their comments and suggestions-you helped me improve the article and made me smile at the same time. Thank you! And, finally, many thanks to Professor Percy Walton for making the publishing experience so agreeable.

Claudia Franziska Brühwiler is a lecturer in American Studies at the University of St.Gallen, Switzerland. She holds a PhD in Political Science and a venia legendi in American Studies. Her published books include Political Initiation in the Novels of Philip Roth (Bloomsbury, 2013) and A Political Companion to Philip Roth (University Press of Kentucky, 2017).

\section{Notes}

1 Showler dissects the conflict surrounding Jubilee Sharpe and the way her ethnicity as well as her back story were sensationalized. Moreover, she looks at an earlier season of The Bachelorette and how one of its black contestants addressed the problem of tokenization (Showler, ch. "Not Going to Say the Words: Race").

2 Detailed accounts of Garrett's appearance on the show can be found on web sites "recapping" The Bachelorette-that is, sites reviewing and summarizing each episode. A primary source for such recaps is RealitySteve (http:/ / realitysteve.com/). In addition, Showler dedicates a section of her book to the conflict between Garrett and other contestants.

3 Courtney Robertson on Season Sixteen of The Bachelor showcased a classic case of villainy. Her ironically titled memoir, I Didn't Come Here to Make Friends: Confessions of a Reality Show Villain, shows to what extent villainy is encouraged by production. See also Showler's discussion of different types of villains on the show (ch. "Gotta Vill: Villains").

4 The casting process of The Bachelor franchise was again criticized during Season Fourteen of The Bachelorette, starring Becca Kufrin. The Huffington Post and RealitySteve covered the back stories of two contestants, bringing to light information that was unknown to both $\mathrm{ABC}$ and the production company: one of the contestants made headlines by liking controversial and offensive social media posts (Fallon and Gray), while another had been charged with and later convicted of indecent assault and battery of a woman (Carbone, "Reader Emails"').

5 The trailer is available on YouTube: https:/ /www.youtube.com/ watch?v=Mked2JksOSA.

\section{Works Cited}

Abdul-Jabbar, Kareem. "The Bachelor' Is Killing Romance in America." Hollywood Reporter. 2 Jan. 2017. 1 Oct. 2017. <http:/ / www. hollywoodreporter.com/news/kareem-abdul-jabbar-bachelor-is-killingromance-america-guest-column-960200>. 
"After the Final Rose." The Bachelor. ABC. Disney-ABC Television Group, Burbank, CA, 13 Mar. 2017. Television.

Arthur, Kate. "'The Bachelorette' Ratings Are Falling Hard." BuzzFeed News. 11 Jul. 2017. 20 Jul. 2018. <https:/ / www.buzzfeednews.com/ article/kateaurthur/the-bachelorette-ratings-are-falling-hard $>$.

Bonilla-Silva, Eduardo. Racism without Racists: Color-Blind Racism and the Persistence of Racial Inequality in America. Lanham, MD: Rowman \& Littlefield, 2014.

Bonilla-Silva, Eduardo, and David Dietrich. "The Sweet Enchantment of Color-Blind Racism in Obamerica." ANNALS of the American Academy of Political and Social Science 634.1 (2011): 190-206. <https:/ / doi. org/10.1177/0002716210389702>.

Boylorn, Robin M. “As Seen on TV: An Autoethnographic Reflection on Race and Reality Television." Critical Studies in Media Communication 25.4 (2008): 413-33. <https:/ / doi.org/10.1080/15295030802327758>.

Brown, Michael K., Martin Carnoy, Elliott Currie, Troy Duster, David B. Oppenheimer, Marjorie M. Shultz, and David Wellman. Whitewashing Race: The Myth of a Color-Blind Society. Berkeley: U of California P, 2005.

Butter, Michael. "Guess Who's Coming to Dinner: Liebe zwischen Schwarz und Weiss im amerikanischen Film und Fernsehen." Von Selma bis Ferguson-Rasse und Rassismus in den USA. Ed. Michael Butter, Astrid Franke, and Horst Tonn. Berlin: Verlag, 2016. 173-90.

Caramanica, Jon, and Amanda Hess. "An Instigator Emerges as the Racial Awkwardness of 'The Bachelorette' Grows." New York Times. 20 Jun. 2017. 1 Oct. 2017. <https://www.nytimes.com/2017/06/20/arts/television/ bachelorette-lee-kenny-paradise.html>.

Carbone, Steve. "The Bachelorette Rachel Episode 3 Recap, My Appearance on Olivia's Podcast, \& DeMario's Ex." RealitySteve. 6 Jun. 2017. 1 Jun. 2018. <http:/ / realitysteve.com/2017/06/06/the-bachelorette-rachel-spoilersepisode-3-recap-podcast-with-olivia/>.

Carbone, Steve. "Podcast \#41-Interview with Josiah Graham (Part 2), \& 'Dr. Reality Steve.'” RealitySteve. 31 Aug. 2017. 1 Jun. 2018. <http:/ / realitysteve.com/2017/08/31/bachelor-in-paradise-4-spoilers-podcast41-josiah-graham-part-2-dr-reality-steve/ > .

Carbone, Steve. "Podcast \#44-Interview with Kenny King (Part 1) \& 'Bachelor' Filming Begins." RealitySteve. 21 Sept. 2017. 1 Jun. 2018. <http:/ / realitysteve.com/2017/09/21/the-bachelor-arie-spoilers-podcast-44kenny-king/>.

Carbone, Steve. "Rachel's Guys." RealitySteve. 3 Mar. 2017. 1 Jun. 2018. $<$ http://realitysteve.com/rachels-guys/>.

Carbone, Steve. "'Reader Emails' and One of Becca's Guys in Some Serious Legal Trouble." RealitySteve. 13 Jun. 2018. 20 Jul. 2018. <http:/ / realitysteve. 
com/2018/06/13/the-bachelorette-becca-spoilers-reader-emails-lincolnadim-indecent-assault-and-battery $/>$.

Chidester, Phil. "May the Circle Stay Unbroken: Friends, the Presence of Absence, and the Rhetorical Reinforcement of Whiteness." Critical Studies in Media Communication 25.2 (2008): 157-74. <https:/ / doi. org/10.1080/15295030802031772>.

Collins, Patricia Hill. Black Sexual Politics: African Americans, Gender, and the New Racism. New York: Routledge, 2004.

Coscarelli, Joe, and Caryn Ganz. "The Bachelorette' Leans on a Racial Conflict, and Nobody Wins." New York Times. 28 Jun. 2017. 1 Oct. 2017. <https:/ /www.nytimes.com/2017/06/28/arts/television/

bachelorette-rachel-lee-kenny.html>.

"Cut for Time: New Bachelorette." Sketch, Saturday Night Live. NBC. NBCUniversal, New York, 6 May 2017. Television.

Deggans, Eric. "The Bachelorette May Have a Black Star, but It's Still Set in a White World." National Public Radio. 23 May 2017. 1 Oct. 2017. <http:/ / www.npr.org/2017/05/23/529705257/the-bachelorette-may-have-a-blackstar-but-its-still-set-in-a-white-world $>$.

Drew, Emily M. "Pretending to Be 'Postracial': The Spectacularization of Race in Reality TV's Survivor." Television \& New Media 12.4 (2011): 326-46. <https://doi.org/10.1177/1527476410385474>.

Dreyer, David R. “Learning from Popular Culture: The 'Politics' of Competitive Reality Television Programs." PS: Political Science E Politics 44.2 (2011): 409-13. <https://doi.org/10.1017/s1049096511000254>.

Du Bois, W.E.B. The Souls of Black Folk. 1903. Ed. Henry Louis Gates, Jr., and Terri Hume Oliver. New York: Norton, 1999.

Dubrofsky, Rachel E. "The Bachelor: Whiteness in the Harem." Critical Studies in Media Communication 23.1 (2006): 39-56. <https: / / doi.org/ 10.1080/07393180600570733>.

Dubrofsky, Rachel E., and Antoine Hardy. "Performing Race in Flavor of Love and The Bachelor." Critical Studies in Media Communication 25.4 (2008): 373-92. <https://doi.org/10.1080/15295030802327774>.

Gray, Emma, and Claire Fallon. "ABC Cast a Guy Who Thinks the NAACP Is 'Racist' to Date First Black Bachelorette." Huffington Post. 31 May 2017. 1 Jun. 2018. <https: / / www.huffingtonpost.com/ entry/lee-garrett-tweets-abc-first-black-bachelorette_us_ 592e3470e4b0e95ac194e127>.

Gray, Emma, and Claire Fallon. "'The Bachelorette's' Garrett Yrigoyen 'Liked' Posts Mocking Immigrants, Parkland Students." Huffington Post. 28 May 2018. 20 Jul. 2018. <https:/ / www.huffingtonpost.com/entry / bachelorette-premiere-garrett-yrigoyen_us_5b0837d9e4b0fdb2aa5342b6>. 
Hasinoff, Amy Adele. "Fashioning Race for the Free Market on America's Next Top Model." Critical Studies in Media Communication 25.3 (2008): 324-43. <https:/ / doi.org/10.1080/15295030802192012>.

Hernton, Calvin C. Sex and Racism in America. New York: Grove, 1965.

Hero, Rodney E., and Morris E. Levy, with Benjamin Radcliff. "The End of 'Race' as We Know It? Assessing the 'Postracial America' Thesis in the Obama Era." Beyond Discrimination: Racial Inequality in a Postracist Era.

Ed. Frederick C. Harris and Robert C. Liberman. New York: Russell Sage Foundation, 2013. 39-72.

hooks, bell. Yearning: Race, Gender, and Cultural Politics. Boston: South End, 1990.

Jackson, Charreah K. "We Still Have to Be Twice as Good: 4 Racial Reality Checks from The Bachelorette's Love Life." Essence. 20 Jun. 2017. 1 Oct. 2017. <http://www.essence.com/love-sex/relationships / the-bachelorette-racial-reality-checks-rachel-lindsay>.

Kaufman, Amy. Bachelor Nation: Inside the World of America's Favorite Guilty Pleasure. New York: Dutton, 2018.

Kim, L.S. “Race and Reality . . TV." Flow Journal 11 (2004). 1 Jun. 2018. <https:/ / www.flowjournal.org/2004/11/race-and-realitytv/?print=print>.

Kraszewski, Jon. "Branding, Nostalgia, and the Politics of Race on VH1's Flavor of Love." Quarterly Review of Film and Video 31.3 (2014): 240-54. <https:/ / doi.org/10.1080/10509208.2013.811355>.

Lawson, Richard. "Please Drop 'The Bachelor' Discrimination Lawsuit." Atlantic. 18 Apr. 2012. 1 Oct. 2017. <https: / /www.theatlantic.com/ entertainment/archive/2012/04/please-drop-bachelor-discriminationlawsuit/329180/>.

Littlefield, Marci Bounds. "The Media as a System of Racialization: Exploring Images of African American Women and the New Racism." American Behavioral Scientist 51.5 (2008): 675-85. <https:/ / doi.org/ 10.1177/0002764207307747>.

Madison, Ira, III. "How 'The Bachelor' Franchise Is Exploiting Race for Ratings." Daily Beast. 24 Jun. 2017. 1 Jun. 2018. <https:/ / www.thedailybeast. com/the-bachelor-franchise-is-exploiting-race-for-ratings $>$.

"The Men Tell All." The Bachelorette. ABC. Disney-ABC Television Group, Burbank, CA, 31 Jul. 2017. Television.

Myers, Vernā, and Julia Fawal. "Why Talking about Race on The Bachelorette Matters." TED. 24 Jul. 2017. 1 Jun. 2018. <https: / /ideas.ted.com/ why-talking-about-race-on-the-bachelorette-matters $/>$.

Pardo, Rebecca. "Reality Television and the Metapragmatics of Racism," Journal of Linguistic Anthropology 23.1 (2013): 65-81. <https:/ / doi.org/ 10.1111/jola.12007>. 
Pascoe, Peggy. "Miscegenation Law, Court Cases, and Ideologies of 'Race' in Twentieth-Century America." Journal of American History 83.1 (1996): 44-69. <https: / /doi.org/10.2307/2945474>.

Rankaduwa, Sandi. "'Bachelorette' Uses Racism as Entertainment-Which Means Nobody Wins." RollingStone. 4 Aug. 2017. 1 Oct. 2017. <http:/ / www.rollingstone.com/tv/news/bachelorette-rachel-lindsay-seasonuses-racism-as-entertainment-w495891>.

Robertson, Courtney. I Didn't Come Here to Make Friends: Confessions of a Reality Show Villain. New York: Dey Street, 2015.

Showler, Suzannah. Most Dramatic Ever: The Bachelor. Kindle ed. Toronto: ECW, 2018.

Shugart, Helene A. "Ruling Class: Disciplining Class, Race, and Ethnicity in Television Reality Court Shows." Howard Journal of Communications 17.2 (2006): 79-100. <https://doi.org/10.1080/10646170600656839>.

Sue, Derald Wing. Race Talk and the Conspiracy of Silence: Understanding and Facilitating Difficult Dialogues on Race. New York: Wiley, 2015.

Tyree, Tia. "African American Stereotypes in Reality Television." Howard Journal of Communications 22.4 (2011): 394-413. <https: / doi.org/10.1080/ 10646175.2011.617217>.

"Week 2: Celebrity Guests." The Bachelorette. ABC. Disney-ABC Television Group, Burbank, CA, 29 May 2017. Television.

"Week 3: Ellen DeGeneres \& More." The Bachelorette. ABC. Disney-ABC Television Group, Burbank, CA, 5 Jun. 2017. Television.

"Week 4: Hilton Head Island." The Bachelorette. ABC. Disney-ABC Television Group, Burbank, CA, 19 Jun. 2017. Television.

“Week 5: Part 1." The Bachelorette. ABC. Disney-ABC Television Group, Burbank, CA, 26 Jun. 2017. Television.

“Week 5: Part 2." The Bachelorette. ABC. Disney-ABC Television Group, Burbank, CA, 27 Jun. 2017. Television.

"Week 7: Hometown Dates." The Bachelorette. ABC. Disney-ABC Television Group, Burbank, CA, 17 Jul. 2017. Television.

Willis, Jay. "Oh Good, The Bachelorette Is Exploiting Racism for Ratings Now." GQ. 20 Jun. 2017. 1 Oct. 2017. <https:/ / www.gq.com/story/

bachelorette-recap-racism-ratings $>$. 